\begin{tabular}{c} 
Volume and Issues Obtainable at Center for Sustainability Research and Consultancy \\
Sustainable Business and Society in Emerging Economies \\
ISSN: $2708-2172$ \& $($ E): $2708-2504$ \\
Volume 3: Issue 2 June 2021 \\
CSRC \\
Journal homepage: $\underline{\text { www.publishing.globalcsrc.org/sbsee }}$ \\
\hline
\end{tabular}

\title{
Promoting Sustainable Tourism in Maldives through Social Media: A Review
}

Aminath Raushan Imad, Faculty of Business, Accountancy, Communication and Hospitality Management, SEGi University, Selangor, Malaysia

*Tak-Jie Chan, Faculty of Business, Accountancy, Communication and Hospitality Management, SEGi University, Selangor, Malaysia

*Corresponding author's email address: chantakjie@segi.edu.my

\begin{tabular}{l}
\hline ARTICLE DETAILS \\
\hline History \\
Revised format: May 2021 \\
Available Online: Jun 2021 \\
\hline Keywords \\
Sustainable Tourism, Social \\
Media, Green Marketing \\
Practices, Sustainable \\
Development Goals, \\
Maldives
\end{tabular}

JEL Classification

L80, L83

\begin{abstract}
Purpose: The archipelago of the Maldives is the main source of attraction to many tourists worldwide, making tourism the largest sector of the country's economy. However, global challenges have become increasingly visible and remote countries like Maldives is facing extreme challenges economically as well as environmentally. With the advancement of the technology, social media marketing being the worthwhile strategic positioning tool. This review article aimed to discuss global tourism industry, the practice of sustainable tourism in the Maldives, followed by the literature incorporates social media marketing in the context of tourism promotion in Maldives.
\end{abstract}

Design/Methodology/Approach: The study is a review paper on sustainable tourism in Maldives context, by focusing on global tourism industry, the practice of sustainable tourism in the Maldives, followed by social media marketing in the context of tourism promotion.

Findings: The review of the sustainable tourism literature found that Maldives as an island are practicing and incorporated green and sustainable practices.

Implications/ Originality/Value: The study provides a prodigious scope for marketing practitioners of tourism industry and provides insights on building a successful social media marketing strategy that may lead to enhance the green image and tourist's intention to revisit.

\section{OPEN ACCESS}

(C) 2021 The authors, under a Creative Commons AttributionNonCommercial- 4.0

Recommended citation: Imad, A. R. and Chan, T. J. (2021). Promoting Sustainable Tourism in Maldives through Social Media: A Review. Sustainable Business and Society in Emerging Economies, 3 (2), 107-114

\section{Introduction}

Tourism is undoubtedly one of the major industries in the world considering its immense contribution to job creation and economic development (Niñerola, Sánchez-Rebull, \& Hernández-Lara 2019). Tourism has become a key driver for socio-economic progress (World Tourism Organization, 2018). The Maldives is recognized for its crystal-clear water and soft sandy beaches which made the country one of the world's famous tourist destinations. Since the beginning of tourism in Maldives in the year 1972, 
with the opening of the first tourist resort, the industry has transformed and developed to be a globally recognized and world-famous travel destination for leisure. The country that located in the Indian Ocean now has 147 resorts with a total of more than 34076 beds in operation attracting tourists over a million each year (Marcus, 2021). Despite the challenges faced due to Covid-19 pandemic, a total of 555,494 tourists were welcomed to the country in the year 2020. In January 2021, arrival numbers stood at 92,103 and it increased to 99,397 by $3^{\text {rd }}$ February 2021 with a daily average of 2,923 tourists (United Nations World Tourism Organization, 2021).

Based on the concept of one-island-one resort, resorts in the Maldives are an establishment on a single low-lying island surrounded by the sea (Zubair \& Bouchon, 2014). Over the past decade, global warming and localized human-made activities have caused an adverse effect on the environment. Hence, they are at high risk and easily affected by climate change, global warming, and the accompanying issues such as rising of sea level (Fardeen, 2019). The effects of climate change are putting the world's most visited destinations at risk. By 2050 climate change could directly lead to elimination of $90 \%$ of coral reefs (Layne, 2017). While the tourism industry will never be fully sustainable, there are steps that need to be taken to protect the planet in the context of tourism. Therefore, it is imperative for the country to focus on sustainability and environment friendliness.

Over the past decade, with the development of information and communication technology, the growing role of social media in tourism promotion is undeniable. With this development it has completely changed the relationship of tourist's behavioural intention towards the destination. It has proven that leveraging off social media to market the sustainable tourist destination is an excellent strategy especially when the destination is promoted with green. In this light, in order to understand the sustainable tourism industry, this review article focuses on the following: global tourism industry, the state of tourism in the Maldives and the practice of sustainable tourism in the Maldives. Following to this, the literature incorporates social media marketing in the context of tourism promotion will also be discussed.

\section{Literature Review}

\section{Global Tourism Industry}

Global tourism evolved from being an exclusive activity for the elites to becoming public tourism in the twentieth century (Triarchi \& Karamanis, 2017). In comparison, 1970 recorded an estimated 165.8 million international tourists, up from 69.3 million that were recorded in 1960 (Scott \& Gössling, 2015). According to the UNWTO (2021) the industry experienced sustained growth as international arrivals increased by $7 \%$ in 2017 and by 6\% in 2018. In 2019, all the regions experienced an increase in tourist arrivals with the Middle East increasing by $8 \%$ whilst both Asia and the Pacific and Europe increased by $4 \%$.

However, due to the advent of the Covid-19 pandemic, the tourism industry was hit the hardest as year 2020 saw international arrivals dropping by 74\% (UNWTO, 2021). In addition, an estimated USD 1.3 trillion in export revenues was lost during this period and between 100 and 120 million direct tourism jobs were put at risk. In particular, Asia-Pacific region saw an $84 \%$ decrease in international arrivals, the Middle East and Africa experienced a 75\%, the Americas 69\% and Europe 70\% (UNWTO, 2021). The year of 2021 seems to be following the same trajectory as most sectors remain shut since most countries and regions across the globe are still battling the Covid-19 pandemic in check.

\section{Tourism in the Maldives Context}

International tourism in the Maldives is synonymous with resort-island as resorts are based on the concept of one-island-one resort. Since the late 1970s, tourism became the main economic sector of the country as well an important source of foreign exchange (Sathiendrakumar, Jaffur, \& Seetanah, 2021). Evolution in tourism sector in the Maldives has its impacts on the population and Gross Domestic Products (GDP). Since the beginning of the establishment of the first resort, the governments turned potential islands into high class resorts only focuses on 5-star quality services that attracted tourists 
across the globe (Giampiccoli, Muhsin \& Mtapuri, 2020). Subsequently, tourism has improved its economy since the discovery of its potential. In the process, the sector has become an indispensable and dominant driver of economic growth in the Maldives (Ahmed, 2018).

As all resort destinations are placed in their natural environment (Kim \& Thapa, 2018), the tourists seek to get the most out of it while visiting the Maldives resorts. The main activities they take part mostly are swimming, snorkelling, and diving, as the main attractions in the country's tourism sector are beach, sea, underwater life, sun, lagoon, islands, and culture (Sae-Tang \& Yamchuti, 2020). The tourist arrival rate in the year 2019 was 1.9 million and by 2023 , the government aims to achieve 2.3 million tourists to visit the Maldives. Hence, with that set target, the country expanded tourism sector for low-budget tourists by developing guesthouses in local islands (Dam, Sabacan, Sim, \& Thirumaran, 2021). However, the tourism sector of the Maldives has noted for some constraints with the concern of high tourist arrivals leading to environmental problems. Moreover, the country is currently facing challenges with regard to the global Covid-19 pandemic and is uncertain with the maintenance of tourist's arrival in the following years.

\section{Tourism and the Maldives' Economy During the Covid-19 Pandemic}

Like at the global level, economies of countries that depend on tourism were heavily affected by Covid19 pandemic as air travel was banned. This hugely decreased the number of international tourist arrivals. Maldives also closed its borders for the purposes of self-protection, thus, the country was also victim of this reality. According to the World Bank (2020), the Maldives was affected by the Covid-19 global pandemic more than any other country in the South Asia region.

The Maldives majorly relies on foreign currency inflows from tourism coupled with foreign investments and loans to finance its huge account deficit. For instance, in the first and second quarters of 2020, GDP contracted by $5.0 \%$ and $51.6 \%$ respectively due to Covid-19 as almost all sectors (and particularly the tourism industry) was at halt. The tourism industry experienced a $14.2 \%$ decrease in the first half of 2020 whilst transportation and communication decreased by $3.8 \%$ and construction by $1.8 \%$ (Asian Development Bank, 2020). Figure 1 below clearly explains the GDP dynamics of the Maldives during the Covid-19 pandemic.

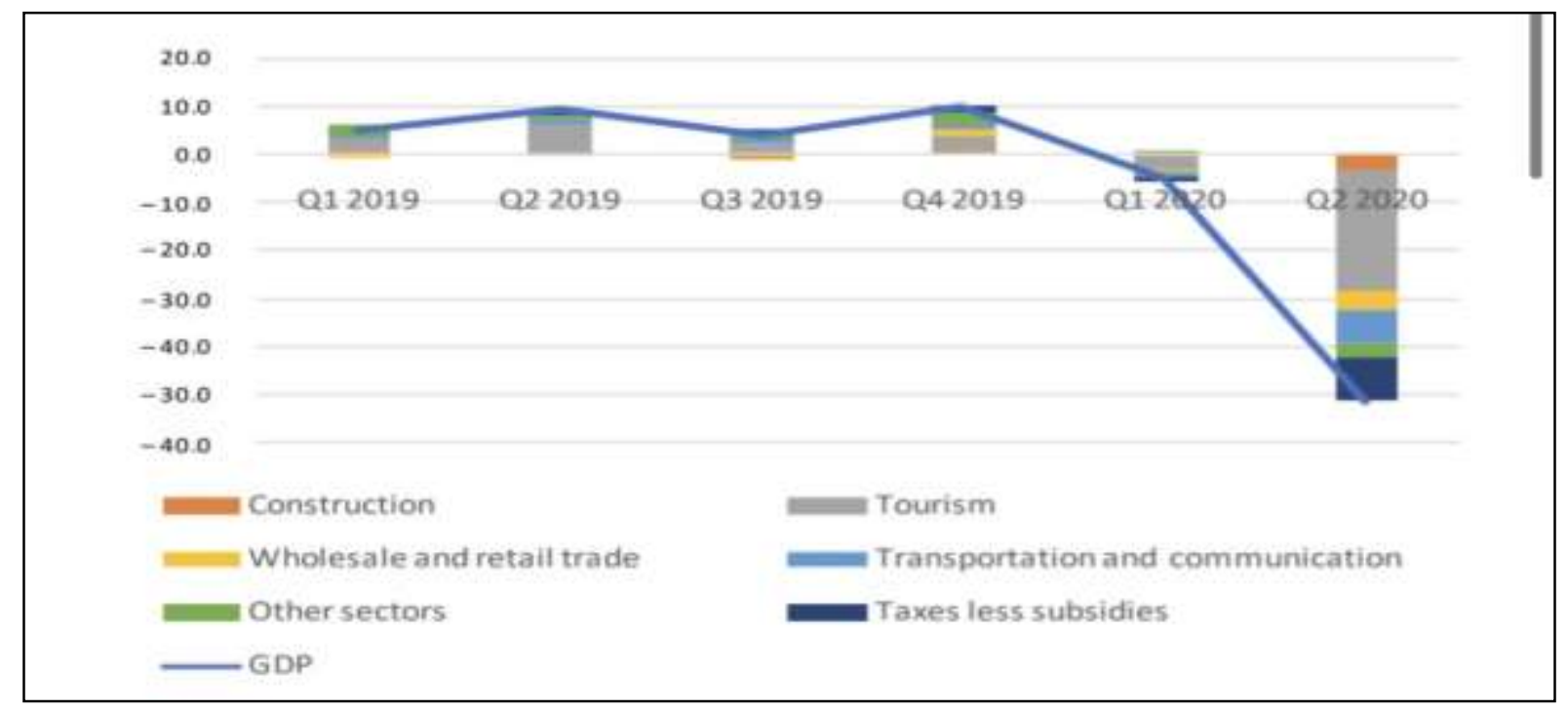

Figure 1: Supply-side Contributions to Growth (Q1 2019-Q2 2020)

Source: Asian Development Bank (2020)

\section{The Practice of Sustainable Tourism}

Sustainable tourism is defined as the responsible type of tourism which generates the administration of natural resources economic and social needs while following the fundamental procedures such as environmental, biological, cultural, and supportive networks (World Tourism Organization, 2017). The 
term sustainability is still being broadly examined and gradually tourism industry is adopting the sustainable factor with the arising concerns for the environment. The $21^{\text {st }}$ century has made clear on some of the severe environmental issues, hence, most businesses including tourism sector had to make environment a priority. Moreover, the close relationship between the environment and sustainability became vital especially remote island like the Maldives.

As the issues related to sustainable development were gathering momentum, they became interwoven with tourism issues that potentially cause environmental and cultural harm, such as, anthropogenic overload of tourist facilities, pollution of ecosystems, and the destruction of national identity and culture. Thus, there was a call in the tourism industry to move towards tourism practices that are not destructive to the natural and social environment. However, today, the tourism sector accounts for about $5 \%$ of global carbon dioxide $\left(\mathrm{CO}^{2}\right)$ emissions, including $40 \%$ for air transport and $20 \%$ for accommodation facilities. Tourism industry is responsible for $4.6 \%$ of radiation pressure, which causes climate changes (Stukalo, Krasnikova, Krupskyi, \& Redko, 2018). The challenges posed by tourism on the environment do not seem to be ending soon, therefore, there is a need to understand sustainable tourism in a more holistic perspective.

The United Nations sponsored a programme spearheaded by the World Commission on Environment and Development (WCED) and the result was the need to focus on the concept of sustainable development because there was a realization in the connection between the natural environment and socio-economic activities. According to the EU Guidebook on Sustainable Tourism for Development, it defines sustainable tourism as "tourism that takes full account of its current and future economic, social and environmental impacts, addressing the needs of visitors, the industry, the environment and host communities" (WTO, n.d.). The ultimate aim is to make sure that the needs of future generations are not compromised in an attempt to satisfy the needs of the present.

While the concept of sustainable tourism has been embraced by many scholars and policymakers as a noble cause, there are concerns when it comes to implementation. A concern raised by Aydin and Alvarez (2020), observes sustainable tourism programmes on supply side (of demand and supply) and neglect the viewpoints of the tourists - "obtaining the support of the tourists is essential for the success of sustainability initiatives". However, a noteworthy issue related to sustainable tourism that emerged from the literature is that no one-size-fits-all solutions to measure its. Following that reason, it is of crucial to devote a sub-section on sustainable tourism specifically related to the Maldives to reveal the unique characteristics it possesses.

\section{The Maldives Case}

As a small island state, the Maldives is especially vulnerable to climate change impacts. These impacts include: (1) sea-level rise causing permanent inundation and flooding, sea-level surges, and erosion; (2) increases in sea and surface temperatures causing changes to island and marine ecosystems; (3) increases in the intensity of extreme weather events, such as severe storms and cyclones causing high waves, winds, and sea surges; (4) changes in precipitation, which can exacerbate the effects of sea-level rise; and (5) increases in sea temperature causing damage to coral reefs and other aquatic life (Stukalo et al., 2018).

The observations made above demonstrate the magnitude of the sustainability problem in the Maldives. For such reasons the government of Maldives challenged other members of the United Nations to take serious action against climate change lest they become "environmental refugees" in the future (Collado, 2016). This means that no matter how much they can do to make their tourism sustainable, they still require other countries to play their part so that they are not put in jeopardy. The literature on the Maldives' sustainable tourism seems to underemphasize the importance of understanding the tourists' demand. As for the issue of social media in relation to sustainability, there seems to be a gap that can be explore because it is not dealt much in detail in the existing literature. 


\section{Social Media Marketing}

The social media serves as a platform where individuals come together and share mutual thoughts, comments, and opinions with no definite restrictions on the time or location. As underlined by Kietzman, Hermkens, McCarthy and Silvestre (2011), the social platforms can be identified through, personal interests, friendship, or professional connection. Social media has transformed the marketing strategies and continues to popularize among the businesses. The latest global social media statistics shows that 4.20 billion people are active social media users. This figure takes up 53.6\% of the global population (Chaffey, 2021). It is also noted that each user spends approximately 2 hours daily and owns 5.5 social media accounts each. Under the most used platforms of social media today are Facebook (2,740 million users), YouTube (2,291 million users), Instagram (1,221), Twitter (353), TikTok (689 million users), and many more (Perrin \& Anderson, 2019).

The scale of new technologies over the past years has transformed the way in managing the social media marketing. According to Li, Larimo and Leonidou (2020) social media marketing is noted as the most worthwhile strategic positioning tool which companies utilize in their marketing strategy to expand their horizons in reaching to a vast audience. The role of social media should not be underestimated as social media platforms are utilized by a multitude of users, especially in an era that has advanced technology. Moreover, with the Covid-19 pandemic, the world was highly depend on the online sources and social media, which reflected the importance of the online web. The central role played by the online platforms, highlights the dominance factor.

\section{The Role of Social Media in Sustainable Tourism Promotion}

With the advent of social media, the tourism industry entered the e-Marketing sphere where tourism promoters are utilizing the attributes and functions of online mediums to get closer to the audience. The role of social media marketing in the tourism industry has contributed tourists to make travel decisions over the past years (Stylos, 2020) and continues to create significant values in their travel experiences (Buhalis, 2019; Zhang, 2020). As highlighted by DeMers (2014), social media contributes to a wide range of courses including content postings, grasping demand for products and services through specific marketing tactics, and to spread awareness to stakeholders about sustainability practices and initiatives by the company. Moreover, with revolution of social media marketing, it has become a vital tool for tourism industry to succeed in their visions and achieve their objectives. Part of this justifies the unique and persuasive power social media in attracting tourists to the destinations and further bringing the holistic change into the scope of sustainable tourism.

The rapid adoption of social media in sustainable destination promotion often creates virtual communities that are built on shared experiences, and therefore, it is important to maintain the trust among these communities for building new social interactions (Gulati, 2021). According to Luck and Gianti (2013), social media has been studied as an effective interactive channel that contributes to the promotion of sustainable consumption practices. As Hardeman, Font and Nawijn (2017), urged that information shared on social media tend to be more pursuasive than the traditional way of marketing, thus, having a favorable impact on tourist's behavioural intentions into choosing sustainable activities. A sustainable tourist can be specified to those who plan to travel for business or leisure, but also have responsible concerns for the society and its environment (Gulati, 2021). As stated, earlier, with the growing awareness of environmentalism, more consumers are choosing products and services that have minimum effect on the environment. In the context of tourism, social media is used most prominently to make certain decisions, social sharing, information exchange, publicity or promotion and trip planning (Gössling \& Stavrinidi, 2016). Hence, social media has been widely acknowledged in gaining public support for sustainability initiatives as it plays a vital role in spreading awareness and information at a quick pace. With the driving force of social media, hence, it opens opportunities for extensive sustainable destination promotion and engaging tourists toward the sustainable choices. 


\section{The Maldives Case}

The introduction of new features and influence of social media attributes has connected social, economic, and environmental spheres of tourism sector as it offers various alternative frameworks that facilitates effective communication. While the concept of social media marketing has been used by many marketing experts at an innovative level, there are yet many features and dimensions not discovered and utilized in the implementation process. Especially, when the concept of sustainable tourism and its promotion is still in a very early stage within the Maldives destination promoters (Waseema, 2017). Although, social media networks are taking up the popularity in the tourism sector, it varies with different demographics of audience (Chaffey, 2021). Ecological advancement, equity, futurity, and holism are some of the concept ideas behind the sustainable factor (Gulati, 2021). Hence, it is important to explore the degree of social media marketing practices implemented in the Maldives.

As discussed earlier, sustainability can be a competitive advantage in the marketing segment. However, most of the literature has focused on physical factors rather than looking from a marketing perspective for promoting sustainable tourism in the Maldives. For instance, the study conducted by Cowburn, Moritz, Birrell, Grimsditch, \& Abdulla (2018) assessed the environmental impacts of resort tourism on coral reefs in the Maldives. Moreover, exploratory case studies have been done in relation to sustainable tourism and environment identifying the existing causes concerning the natural environment (Eiseman, 2018; Sae-Tang \& Yamchuti, 2020). However, these studies does not highlight the promotion of green image nor the importance of social media marketing. Promoting green image from the marketing perspective has limited attention in previous studies as the main focus in rising environmental issues are mostly through exploitation of resources and environmental related activities. However, the previous literature has suggested to find ways to preserve the green image and maintain the sustainable factor especially the countries that rely on tourism (Eiseman, 2018).

\section{Conclusion}

As a conclusion, tourism is one of the sectors that falls under the danger zone with its substantial risks related to environmental issues. Hence, sustainable tourism has been an integral part of the development of the Maldives. However, main bodies promoting sustainable tourism are challenged by the limitations in knowledge for social media marketing tactics, which effects the green image of the industry and tourist's arrival rate. Emerging online media communications and social media attributes offer extensive possibilities for bringing up the green image and managing tourist relations in a way that can influence tourist's to repeat their intentions on visiting the resorts that practice sustainable tourism. Moreover, with this contribution to the greater course, the country can benefits both environmentally as well as economically.

\section{References}

Ahmed, M. (2018). Guest houses in the Maldives: Current integration and proposal towards community based tourism. (Unpublished doctoral dissertation). L'Universite de Nantes Comue Universite Bretagne Loire.

Asian Development Bank, (2020). Maldives economic update. ADB. https://www.adb.org/sites/default/files/institutional-document/674971/maldives-economic-update2020.pdf

Aydın, B. \& Alvarez, M.D. (2020). Understanding the tourists' perspective of sustainability in cultural tourist destinations. Sustainability, 12(21), 8846. doi:10.3390/su12218846

Buhalis, D. (2019). Technology in tourism-from information communication technologies to eTourism and smart tourism towards ambient intelligence tourism: A perspective article. Tourism Review, 75(1), 267-272. doi:10.1108/TR-06-2019-0258

Chaffey, D. (2021). Global social media research summary 2021. Smart Insights. https://www.smartinsights.com/social-media-marketing/social-media-strategy/new-global-socialmedia-research/ 
Collado, R. (2016). Vanishing island nations: The case for the Maldives. Geopolitical Monitor. www.geopoliticalmonitor.com/vanishing-island-nations-the-case-for-the-maldives

Cowburn, B., Moritz, C., Birrell, C., Grimsditch, G., \& Abdulla, A. (2018). Can luxury and environmental sustainability co-exist? Assessing the environmental impact of resort tourism on coral reefs in the Maldives. Ocean \& Coastal Management, 158, 120-127. doi: 10.1016/j.ocecoaman.2018.03.025

Dam, M. X., Sabacan, R. F. J., Sim, K. S., \& Thirumaran, K. (2021). Geophysical and cultural realities: Tourism policy of Bhutan and Maldives. In Azzali, S., \& Thirumaran, K. (Eds.). Tropical Constrained Environments and Sustainable Adaptations, Managing the Asian Century, 115-130. doi:10.1007/978-981-33-4631-4_7

DeMers, J. (2014). The confluence of content and social media: Insights for success in 2014. Forbes.www.forbes.com/sites/jaysondemers/2014/02/04/the-confluence-of-contentand-socialmedia-insights-for-success-in-2014/2/

Eiseman, D. (2018). Marketing sustainable tourism: Principles and practice. In Camilleri, M. A. (Ed.) Tourism Planning and Destination Marketing, Emerald Publishing Limited, Bingley, 121-140. doi:10.1108/978-1-78756-291-220181006

Fardeen, M. (2019). Climate change and it's effects on the Maldives. https://storymaps.arcgis.com/stories/a8f8b5b0477f458ea70826756b46a275

Giampiccoli, A., Muhsin, B. A., \& Mtapuri, O. (2020). Community-based tourism in the case of the Maldives. Geojournal of Tourism and Geosites, 29(2), 428-439. doi: 10.30892/gtg.29204-479.

Gössling, S. \& Stavrinidi, I. (2016). Social networking, mobilities, and the rise of liquid identities. Mobilities, 11(5), 723-743. doi: 10.1080/17450101.2015.1034453

Gulati, S. (2021). Social and sustainable: Exploring social media use for promoting sustainable behaviour and demand amongst Indian tourists. International Hospitality Review. (Vol. No. aheadof-print), doi: 10.1108/ihr-12-2020-0072

Hardeman, G., Font, X., \& Nawijn, J. (2017). The power of persuasive communication to influence sustainable holiday choices: Appealing to self-benefits and norms. Tourism Management, 59, 484493. doi:10.1016/j.tourman.2016.09.011

Kietzmann, J., Hermkens, K., McCarthy, I., \& Silvestre, B. (2011). Social media? get serious! Understanding the functional building blocks of social media. Business Horizons, 54(3), 241-251. doi: 10.1016/j.bushor.2011.01.005

Kim, M. \& Thapa, B. (2018). Perceived value and flow experience: Application in a nature-based tourism context. Journal of Destination Marketing and Management, 8, 373-384. doi: 10.1016/j.jdmm.2017.08.002.

Layne, D. (2017). Impacts of climate change on tourism in the coastal and marine environments of Caribbean small island developing states (SIDS). Caribbean Marine Climate Change Report Card: Science Review 2017, 174-184.

Li, F., Larimo, J., \& Leonidou, L. (2020). Social media marketing strategy: definition, conceptualization, taxonomy, validation, and future agenda. Journal of the Academy of Marketing Science, 49(1), 51-70. doi: 10.1007/s11747-020-00733-3

Luck, E. \& Ginanti, A. (2013). Online environmental citizenship: Blogs, green marketing and consumer sentiment in the 21st century. Electronic Green Journal, 1(35), 1-26. doi:10.5070/G313512901

Marcus, L. (2021). How the Maldives became the biggest 2020 international tourism success story. CNN Travel. https://edition.cnn.com/travel/article/maldives-tourism-arrivals-coronavirus-intlhnk/index.html

Niñerola, A., Sánchez-Rebull, M., \& Hernández-Lara, A. (2019). Tourism research on sustainability: A bibliometric Analysis. Sustainability, 11(5), 1377. doi: 10.3390/su11051377

Perrin, A., \& Anderson, M. (2019). Share of U.S. adults using social media, including Facebook, is mostly unchanged since 2018. Pew Research. https://www.pewresearch.org/facttank/2019/04/10/share-of-u-s-adults-using-social-media-including-facebook-is-mostly-unchangedsince-2018/ 
Sae-Tang, N., \& Yamchuti, H. (2020). Relationship between sustainable tourism and environment: Case studies of Maldives and Amphawa floating market, Thailand. Journal of Humanities and Social Sciences, 15(1), 149-160.

Sathiendrakumar, R., Jaffur, Z. K., \& Seetanah, B. (2021). The role of international tourism in the Maldives. CAB International.

Scott, D., \& Gössling, S. (2015). What could the next 40 years hold for global tourism?. Tourism Recreation Research, 40(3), 269-285. doi: 10.1080/02508281.2015.1075739

Stukalo, N. V., Krasnikova, N., Krupskyi, O. P., \& Redko, V. (2018). Fostering sustainable tourism in global economy. International tourism and tourism business, 39(42), 27.

Stylos, N. (2020). Technological evolution and tourist decision-making: A perspective article. Tourism Review, 75(1), 273-278. doi:10.1108/TR-05-2019-0167

The World Bank (2020). Maldives development update: unprecedented crisis presents 'green growth' opportunities. Maldives Development Update. https://www.worldbank.org/en/news/feature/2020/06/18/maldives-development-update-covidcoronavirus-green-growth-opportunity

Triarchi, E., \& Karamanis, K. (2017). Alternative tourism development: A theoretical background. World Journal of Business and Management, 3(1), 35-54. doi: 10.5296/wjbm.v3i1.11198

United Nations World Tourism Organization (n.d.). EU Guidebook on Sustainable Tourism for Development. UNWTO https://www.unwto.org/EU-guidebook-on-sustainable-tourism-fordevelopment

United Nations World Tourism Organization (2021). 2020: Worst year in tourism history with 1 billion fewer international arrivals. UNWTO. https://www.unwto.org/news/2020-worst-year-in-tourismhistory-with-1-billion-fewer-international-arrivals

Waseema, M. (2017). Enhancing destination competitiveness for a sustainable tourism industry: The case of Maldives. OIDA International Journal of Sustainable Development, 10(2), 11-24.

World Tourism Organization (2018). International tourism highlights, 2018 edition. UNWTO, Madrid. https://www.e-unwto.org/doi/pdf/10.18111/9789284419876

World Tourism Organization (2017). UNWTO tourism highlights: 2017 edition. UNWTO, Madrid, https://doi.org/10.18111/9789284419029

Zhang, T. (2020). Co-creating tourism experiences through a traveller's journey: A perspective article. Tourism Review, 75(1), 56-60. doi:10.1108/TR-06-2019-0251

Zubair, F., \& Bouchon, F. (2014). Maldives as a backpacker's destination: Supply and demand perspectives. Social and Behavioral Sciences, 144, 256-263. doi: 10.1016/j.sbspro.2014.07.294 